\title{
Causes, Processes and Effects of Rural Land Certification in Amhara Region, Ethiopia: A Review Article
}

\author{
Mengistie Mersha Enyew ${ }^{1,2}$ \\ 1. Lecturer, Yom Post Graduate College, Gondar, Ethiopia \\ 2. PhD candidate, University of Gondar, Gondar, Ethiopia
}

\begin{abstract}
Land is a crucial resource for rural communities of Ethiopia for more than $85 \%$ of the population is engaged in agriculture. However, land policy in Ethiopia has been a very debating and controversial issue for the last few decades. The debates revolve around state versus private ownership of rural land. The current government of Ethiopia preferred state ownership of land and for which it has received serious critics form opposition political parties, academia, international organizations, and donors. The basic reason behind the critics is that state ownership of rural land creates tenure insecurity, discourages long-term investment on land, and decreases productivity. As a response to these critics, the government of Ethiopia has implemented a rural land certification program in its major regional states, including Amhara regional state. The major objective of this paper was, therefore, to systematically review such land-related issues as land tenure history of Ethiopia; debates related to modes of land ownership; land policies; and causes, processes \& effects of rural land certification. As the review clearly indicates the controversial issue of rural land is still unresolved. It is possible to say that the rural land certification program could not bring meaningful positive effects compared to its intended objectives. There is still a considerable amount of tenure insecurity in the minds of the land holders; farmers prefer short-term investment on land; and land productivity is very low in Amhara regional state.
\end{abstract}

Keywords: Land Tenure, Land Policy, Land-Related Debate, Land Certification

DOI: $10.7176 / \mathrm{JRDM} / 71-04$

Publication date: November $30^{\text {th }} 2020$

\section{Introduction}

\subsection{Land as a resource}

Land is a major asset in modem as well as traditional societies. As a consequence, the way in which property rights to land are defined is of great importance for economic growth, effective use of this resource, governance at the local level, poverty reduction, and opening up of productive opportunities for the poor. Deininger and Feder (2002) ascertain that land continues to remain the primary means for generating livelihood as well as the main vehicle to invest, accumulate wealth, and transfer it between generations.

For rural residents of Ethiopia, land is the primary means of production used to generate a livelihood for a household. It is also the main asset that farmers have to further accumulate wealth when possible and, equally importantly, what they transfer in the form of wealth to future generations. Accordingly, the feeling of security that they have on their holdings affect the households' income, their incentive to work and invest, their desire to use their land in a sustainable manner and even their social and economic status in their respective communities (EEA 2002; Desalegn 1994).

\subsection{An overview of Ethiopia's land tenure systems}

In Ethiopia land tenure system changes with regime change. It is generally acknowledged that the pre-1975 land tenure system in Ethiopia had been one of the most complex tenure systems in the world and had not been thoroughly studied (Desalegn 1984; Cohen and Weintraub 1975; Dejene 1999). The country's geographical, ethnic and cultural diversity and its historical background were mentioned among those factors that produced highly differential forms of land utilization and ownership. Such complex nature of that tenure is also noted as playing a major part in hindering any serious progress towards a reform of the system. During this time, variety of classifications and approaches were used to describe the land tenure system. Among others, rist (kinship), private, state, church and communal land tenure designations were used (Desalegn 1984). Land was sold and exchanged though private holders had no absolute rights. The general land tenure system was a tenant-landlord relationship. The major problems of this land tenure system were exploitative tenancy, land concentration in the hands of the few, and tenure insecurity (Berhanu, Adenew and Gebreselasie, 2003; Deininger et al, 2003; Yigremew 2002; Ege, 1997).

When the Derg came in to power in 1975, public ownership of all rural land had been proclaimed. In the proclamation, transfer of land by sale, exchange, succession, mortgage or lease was prohibited. Hence, the right to own land was vested in the hands of the state since the 1975 land reform. Farmers had only usufruct right (Teketel 1998). During this period, the major problems observed in the land tenure system were fragmentation of holdings, tenure insecurity, land degradation, and lack of appropriate land use (Yigremew, 2002). 
After the downfall of the Derg, the current government of Ethiopia reformed the land tenure system. In 1995, the issue of land tenure system was stated in the constitution of the country in favor of public ownership of land. Article 40 of the 1995 constitution declares that the right to ownership of rural and urban land is entirely entrusted in the state which says "land is a common property of the nations, nationalities and peoples of Ethiopia and shall not be subject to sale or other means of exchange" (FDRE, 1995). Therefore, peasants have only use right on their holdings. Land sale, exchange and mortgage are prohibited by law and hence resulted in decreased investments on land, increased tenure insecurity, and discouraged the emergence of land market (Ege, 2017).

\subsection{The current land laws \& policies}

Federal Level: - the 1995 federal constitution of Ethiopia approved and confirmed the state ownership of land (FDRE, 1995). This constitution gives the state immense political and economic power over the farming population as land is state property, and this creates fear of eviction for political or any other reasons. Moreover, Rural Land Administration and Use Proclamation 456/2005 of the federal government states that the holder of rural land who is evicted for purpose of public use shall be given compensation proportional to the development he has made on the land and the property acquired. Both the article in the constitution and the federal proclamation state that holder of rural land can be evicted for purpose of public use of land. These imply that the government has the right to confiscate rural land for the so-called development programs, public purposes and to provide land for private investors (Woldegebreal, 2013).

Regional Level: - as per the Revised Rural Land Administration and Use Proclamation Number 133/2006 of Amhara National Regional State, a farm household can lose use right to land if one of the following conditions is satisfied. First, if the holder earns a living from non-farm activities; second, if the holder disappears for five consecutive years without notice to the concerned administration body; third, if the land is not used for farming for three consecutive years for rain-fed land and only one year for the irrigated land; and lastly, if the landholder grossly mismanages the land. Moreover, as per Proclamation Number 133/2006 (article 28, sub-article 1) of the regional government, the Rural Land Administration and Use Authority may expropriate rural land from any holder or user when needed for the public service.

\subsection{Debates on Ethiopian land tenure system}

From the very beginning, the current government of Ethiopia declared state ownership of rural land and this was enshrined in the 1995 constitution and hence peasants have been granted usufruct rights. A study made by Yigremew (2001a) shows that there is a debate on land tenure issue among different stakeholders and the focus is on ownership issues and a dichotomy of views on state versus private ownership. Political parties, scholars, donors, and other parties are involved in such debate. While state ownership of land is strongly advocated by the ruling party, private ownership is favored by western economic advisors, international organizations, opposition political parties and some scholars as well (World Bank, 1992). Those pro-state ownership (mainly the ruling party) argue that private ownership will lead to concentration of land in the hands of a few who have the ability to buy, to eviction of the poor peasants, landlessness, and rural-urban migration of the same peasants who are left without any alternative means of livelihood (Yigremew 2002).

On the other hand, many of those political parties that are in opposition to the current ruling party have opted for private ownership of land. There are also some scholars supporting this position. The usual argument forwarded by rivalry political parties, researchers and international donors against the state/public ownership of land is one that focuses on lack of tenure security. For them, state ownership of land by default creates tenure insecurity since, they argue, the government may use land as political weapon by giving and taking it away when needed (Tesfaye 2006). They argue that absence of tenure security for land users provides little or no incentive to improve land productivity through investment in long-term land improvement measures, increases transaction cost because of land dispute, and hinders the emergence of property market such as, credit availability/land mortgage (Desaalegn, 2006). The other issue commonly noted by those political parties is the issue of peasants' unrestricted economic rights on land including the right to sell (Mesfin, 1999). Those who scholarly argue towards this anti-state land ownership position do, implicitly or explicitly, also support this argument. In support of private ownership, Desalegn (1992:53) strongly stated as: "the only way peasant confidence will be restored, and insecurity of tenure abolished thus enabling peasants to take their land as their assets and to work it with great effort, is if peasants are assured that no one can take their land from them".

\section{Rural Land Certification in Amhara Region}

\subsection{Driving forces for land certification}

Both the federal and regional laws and proclamations in Ethiopia claim that rural land shall be owned by the state rather than individual farmers. These laws and proclamations stated that land holders are liable to lose their land when it is needed for public use, development programs and investment purposes. Knowing the essence of these laws and proclamations, most Ethiopian farmers have developed a sense of land tenure insecurity and hence 
refrained from implementing long term investments on their farm lands. Aware of the existence of land tenure insecurity in the minds of farmers, the Ethiopian government has introduced a rural land registration and certification program in most regional states. So, the basic reason for implementing rural land certification was the expectation that it will enhance tenure security, stimulate increased investment and resource productivity, encourage environmental protection, facilitate access to credit, promote the emergence of efficient land use-right markets and provide database that is valuable for land-use planning and taxation purposes (Holden and Tewodros, 2008).

\subsection{The land certification process}

There is evidence that tenure insecurity has hindered investment in land, including the slow progress in land conservation. A study by the Ethiopian Economic Association and the World Bank (Deininger et al., 2003) showed that past history of land redistribution has created a feeling of tenure insecurity. According to Ege (1997), the land re-distribution that took place in Amhara region in 1997 reinforced a sense of land tenure insecurity among the farming communities. Moreover, the regional proclamation (proclamation number 133/2006) stipulates that those who are absent from their residence (kebele) for more than two years will lose access to land, and also creates problem over inheritance, further reinforces perceptions of insecurity over land rights and inhibits migration.

As a way out from pressures, registration of landholdings and granting land use certificates to land holders has recently become government policy in Ethiopia. Amhara region started formal land registration in 2003 next to Tigray regional state (Berhanu \& Fayera, 2005). Land registration \& certification in Amhara was meant to serve two purposes: improving tenure security and encouraging land and natural resources conservation and rehabilitation. Established in 2000, the Environmental Protection Land Administration and Use Authority (EPLAUA) was coordinating land registration in Amhara region. There was also a representative of EPLAUA at the zonal level, although the role of zonal government offices has been reduced since the new decentralization policy of 2001. The woreda level EPLAUA desk, situated in the woreda Rural Development Division, was actively involved in the planning and execution of the land administration, registration and certification activities.

In fact, the actual plot measurement and registration tasks were carried out by kebele land administration committee members. A study by SARDP (2010) states the rural land registration and certification process in Amhara region as follows. In each kebele, farmers were selected and trained to do the land measurement and registration activities. No GPS was used rather the area of a plot was estimated (using traditional methods). Boundaries are visited by the committee in the presence of other witnesses and then described in words. This information and the approximate location (names of neighbors) are filled in with the name of the husband and wife on a form supplied by EPLAUA. Finally, the information was listed on a certificate which was given to the farmers with an official stamp and photo of the household head and wife. The certificate given to land holders is named as Book of Holding. The Book of Holding contains the official certificate showing that those named within are the rightful users of the land described in the book. Inside the Book, a precise description of the parcels that together constitute the holding of the land user is given, including specifics of the area, such as the name of the place where they are located. In order to specify the location of the parcels, the names of other landholders to the north, east, south and west are recorded. The fertility and present use of the land are also described.

As indicated by SARDP (2010), the land registration and certification process in Amhara region has passed through seven steps:

(1) Preparation and awareness raising - the kebele land evaluation and registration process started with giving information to the woreda and kebele administration and conducting awareness campaigns among the farmers. Land Administration Committees (LAC) are then established and members are elected and trained from each kebele;

(2) Application and identification - all farmers are encouraged to apply to the LAC for registration of their land by filling in their names, number of parcels and total area claimed. The application also contains a description of present land use and gives space to write the names of the neighbors east, west, north and south. The LAC verifies the information in the field and enters the checked information in a field sheet;

(3) Temporary certificate - based on the field sheet, the woreda EPLAUO (Environmental Protection, Land Administration and Use Office) issued a temporary certificate to the farmer. This is expected to give farmers proof of their tenure rights at an early stage;

(4) Public hearing - after the temporary certificate has been issued to the land users in each kebele, the results are publicly displayed for one month. The LAC also invited all concerned farmers to a public hearing during which all the applications are read out aloud for discussions and, hopefully, for agreement. Any justified corrections are added to the field sheets and approved by the LAC chairperson and the woreda EPLAUO head;

(5) Registration - information from the field sheets is registered in the Land Registry Book, which is kept at the woreda office. When cases of conflicts were reported, the registration process was proceeding by resolving conflicts side by side; 
(6) Book of Holding and Primary Certificate - based on the information entered into the Land Registry Book, the woreda administration office issued a Book of Holding for each registered household. This booklet contains the name and picture of the owners, list of family members and address, as well as basic rights and obligations according to the law. It also contains the official certificate of a household's right to use their land - the Primary Certificate;

(7) Secondary Certificate and Mapping - as a detailed description of the parcels was needed for the secondary certificate, so a survey is carried out and boundary corners are marked by permanent corner stones. Based on this information, maps of the area are created and distributed to the landholders.

Generally, seven categories of land users have been listed in the registration and certification process. These are male holders, female holders, joint holders (both husband and wife), group land users, kebele administration, NGOs and government organizations.

\subsection{Effects of land certification in Amhara region}

Land policy has remained controversial in Ethiopia since the fall of the Derg regime in 1991. Broadly speaking, Crewett \& Korf (2008) distinguished two antagonistic political discourses on the land question of Ethiopia: (1) the discourse of fairness and state protection that is arguing for state ownership, and (2) the discourse of privatization and efficiency. The former is the position of the government that remains critical of privatizing land holdings. The government expects privatization to foster the concentration of land ownership in few hands by crowding out poor, destitute farm families from their land. On the other hand, critics of the government's position argue that state ownership of land discourages long-term investment on land, increases land tenure insecurity, prevents the development of a land market and thereby holds down productivity, (EEA/EPRI, 2002; Desalegn, 2004).

As a solution to the critics against state ownership of rural land, the Ethiopian government has implemented a rural land registration and certification program in four major regional states of the country. Amhara regional state has implemented the rural land certification process since 2003 (Berhanu \& Fayera, 2005). The rural land certification program was expected to solve all the weaknesses of state ownership of rural land and thereby increase tenure security, promote long-term investment, encourage land market and increase productivity. However, as a number of studies clearly show, the real effects of the rural land registration and certification program in Amhara region are mixed: while some show success in terms of the intended objectives, other studies indicate otherwise. The next section presents the effects of the land certification program in Amhara region.

Security Effect: - there are a number of studies claiming to show various positive impacts of land certification on tenure security and economic development. For instance, Berhanu \& Fayera (2005), SARDP (2010) and Belay (2010) indicated that farmers in Amhara region have developed better tenure security after the land certification program. Similarly, Mengesha et al. (2019) in their study in Gozamin district of Amhara region found out that there is a positive correlation between land certification and land tenure security.

On the other hand, Ege (2017) supported by evidences from North Shewa, Amhara region, indicated that tenure insecurity increased after land certification. The result of his research is against those studies that indicate positive association between land certification and tenure security for available data on tenure issue after certification show so high levels of insecurity. His study showed that the level of tenure insecurity is higher for the youth than other age groups. Most youths have more demand for a fresh land redistribution than ever in the past while elderly landowners fear it (ibid). Despite the massive registration of rural land-use rights and issuing of millions of land certificates in the Amhara region, there is still considerable tenure insecurity; because the fear of further redistribution of land like that of 1997 will occur at some point in the future lingers in the minds of the peasantry (Dessalegn 2004; Berhanu and Fayera 2005; Tesfaye 2003). A study by Dessalegn (2009) from two districts found that despite land certification, a significant percentage of households reported that they expected land redistribution in the future, which may increase tenure insecurity. In addition, the Revised Amhara National Regional State Rural Land Administration and Use Proclamation No. 133/2006 (article 8, sub-article 2) states "where the land holders residing in one kebele and where not less than 80 per cent of them request the Authority in writing for land distribution, the land re-distribution may be carried out" which signifies the possibility of land distribution is not closed.

Furthermore, the guarantees provided in the federal and regional proclamations that every individual over the age of 18 years will have access to rural land if he/she desires to engage in an agricultural pursuit engenders tenure insecurity in communities whose lands are fully occupied and used because this can be done only through subdivision and redistribution of land. Similarly, the inclusion, in regional land-use legislations, of threats to dispossess land-use rights of individuals in case of mismanagement without defining precisely what actions or omissions constitute mismanagement engender tenure insecurity (Berhanu and Fayera 2005). Above all, the federal constitution (the mother of all laws in the country) and the regional constitution as well as proclamations at the federal and regional level clearly indicated that rural land is owned by the state which is a source of insecurity despite land certificate is given.

Collateral Effect: - experiences from many countries in the world indicate that bankers hold titled land as 
collateral for lending. For instance, farmers with titled land in Thailand obtained as much as $500 \%$ more institutional credit than those with untitled deeds (Feder et al. 1988). In a number of countries in Latin America (Bolivia, Chile, Honduras and Paraguay), farmers with title deeds had easier access to bank financing (Munoz 1993). On the other hand, for most smallholders in Sub-Saharan Africa (Rwanda, Senegal, Uganda, and Somalia), access to institutional finance is very limited (Bruce and Migot-Adholla 1994). Because land-use rights cannot be mortgaged in Ethiopia by law (FDRE constitution, 1995), the opportunities for profitable investment in the rural areas are very few and the rural financial system is underdeveloped, and hence one can conclude that there will be virtually no benefit to be gained from the collateral effect of rural land titling in Ethiopia.

Land Rental (Market) Effect: - The theoretical argument for this effect is that land titles provide unequivocal proof of ownership of use-rights, thus providing enhanced security that improves the functioning of the land-use rights market. In principle, land certification removes the fear of farmers being dispossessed by the tenant or by their own community if they rent out their land and/or seek off-farm employment. A study by Samuel (2005) cited in Samuel (2006) has found that the number of land transactions (both rental and sharecropping) is high and has positive impacts of land rental markets in terms of improving the allocation efficiency of factors of production. The Rural Land Administration and Use Proclamation No 133/2006 clearly declares that any land holder may transfer his using right in rent to any person either in the form of sharecropping or fixed cash rent though this right is bound with conditions. Land use right holders are restricted on the amount of land and the period for which they can give out their land for rent. Furthermore, there is a residency requirement stipulating that if land use right holders reside away from the area where the plot is located for more than 2 years, they will lose their rights to use the land. And hence, these obstacles have imposed a significant negative impact on the functioning of land rental market.

Land Management Effect: - several studies suggest that land certification program in Ethiopia induced better land management practices like tree planting and construction of stone terraces which ultimately improved land productivity (Deininger et al., 2011; Holden et al., 2009). Similarly, a study in Amhara region (Assefa, 2010) indicated that most farmers in the region have got a good motivation to engage in land management practices after their land is certified. However, Ege (2017) argues that farmers preferred applying short-term land management practices to long-term investments.

Land-Related Dispute Resolution Effect: - various studies indicated that land-related disputes have been highly reduced after the implementation of rural land certification in Amhara region (Berhanu \& Fayera, 2005; Holden \& Tewodros, 2008). Similarly, Deininger et al (2011), in their study, reported that there is a marked reduction in land-related conflicts due to clarification of boundaries and field-based adjudication that were undertaken during the certification program. However, the findings of Ege (2017) are quite different which indicate that the current land laws are not well thought through and produced an exceptional level of conflict and uncertainties. Supported by evidences from field, Ege argue that disputes related with inheritance are especially increasing after the land certification. The reason for the increase in inheritance conflicts in the peasant community is partly due to the high stakes. This is accentuated by rules that may sometimes lead to rather surprising outcomes. Such rules pave the way for dirty tricks. In such cases, the sense of betrayal created extreme bitterness. In the worst of cases there is fear that somebody may be killed.

Expropriation \& Compensation Effect: - the impact of rural land certification on expropriation and compensation in Amhara region is different by different research findings which might be based on the nearness or farness of the study sites from urban centers, surface transport networks, investment sites, etc. Because, the issue of land expropriation and compensation are believed to be highly linked with such variables. A study by SARDP (2010) confirmed that land certification protected land holders from arbitrary eviction; and if the certified land is needed for public use or other development programs, the certificate enabled them to get timely and appropriate compensation.

To the contrary, other studies clearly indicated the presence of wide grounds of land expropriation without certificate holders' consent and absence of adequate, timely and sufficient compensation during expropriation (Weldegebreal, 2013). Land holders surrounding urban centers, near to investment sites, and closer to surface transport networks are frequently suffering from land expropriation with very small compensation which can be gained after several ups and down.

\section{Conclusion}

Land is an important issue for the majority of Ethiopian people who, directly or indirectly, depend on agricultural production for their income and subsistence. As a result, land has been and continues to be the primary means for generating livelihood as well as the main vehicle to invest, accumulate wealth, and transfer it between generations. However, the way how the rural community access land has been a matter of debate for the last few decades. The majority of the rural people have never got full ownership on the land they used to earn their livelihood. It was either owned by few landlords (imperial period) or the state (Derg and current regimes). So, rural land is both an economic and a political/social question in the present-day Ethiopia. The current government of Ethiopia preferred 
state ownership of rural land and stated it in its constitution. However, the government is continuously being criticized for its state ownership policy of rural land. Those criticizing state ownership of rural land argued that it yields tenure insecurity, discourages long-term investment on land, and decreases land productivity.

As a solution for weaknesses emanating from state ownership of rural land, the government of Ethiopia has implemented a rural land registration and certification program in its major regional states including Amhara region - the focus of this study. Evaluated in terms of its intended objectives, it can be stated that the certification program has brought very limited positive effects. There are still feelings of tenure insecurity in the minds of the land holders which can be manifested in various forms. Due to the growing number of landless youths in the rural community, farmers with certified land holding are still afraid of land distribution. Besides, the regional land proclamation states that land distribution may be considered if a large number of people in a kebele (lowest administrative unit) have a desire for land distribution.

Relatively speaking, it can be said that the issuance of land certificates has brought positive effects in terms of encouraging landholders to invest on land. However, most investments on land are still preferred to be shortterm investments which indicate the presence of some sort of fear and insecurity. Similarly, the certificate has benefited the right holders to some extent in terms of improving land rental markets and reducing border disputes between neighbor landholders. However, it should be noticed that the effects of land certificate on investment, dispute resolution and land market are far below the expectations. Surprisingly, all literatures consulted in this study revealed that land certificates had brought no benefit for landholders pertaining to lending money from normal financial institutions (banks). This is so because it is boldly stated in the constitution that land-use rights cannot be mortgaged in Ethiopia. Similarly, the role of the land certificate in protecting landholders from expropriation is negligible. Landholders near to urban centers, investment areas, and surface transport networks can lose their land any time when the land is needed.

\section{References}

Belay, A. (2010). The effects of rural land certification in securing land rights: a case of Amhara region, Ethiopia. Unpublished thesis submitted to the international institute for geo-information science and earth observation, the Netherlands.

Berhanu Adenew and Fayera Abdi (2005). Land Registration in Amhara Region, Ethiopia (Research Report 3), IIED, November 2005

Berhanu Nega, Adenew Berhanu and GebreSelassie S. (2003). Current Land Policy Issues in Ethiopia. In Land Reform, Land Settlements and Cooperatives 2003/3. Special Edition. P. Groppo, ed. Rome: Food and Agriculture Organization

Bruce. J. W., and S. E. Migot-Adholla (1994). Are indigenous African tenure systems insecure? In Searching for land tenure security in Africa, edited by J. W. Bruce and S. E. MigotAdholla, 1-10. Washington D.C.: World Bank.

Cohen, John and Weintraub (1975). Land and Peasants in Imperial Ethiopia: The Social Background of a Revolution. Van Gorkum, Assen.

Crewett, W., \& Korf, B. (2008). Ethiopia: Reforming land tenure. Review of African Political Economy, 35(116), 203-220.

Deininger, K. and Feder, G. (2002). Land Institutions and Policy: Key messages of the Policy ResearchReport. A Paperpresented at a Workshop on Land Institutions and Land Policy Consultations for a World Bank Policy ResearchReport. Kampala, Uganda, April -29 -May 2

Deininger, K., Ali, D., and Alemu, T. (2011). Impacts of land certification on tenure security, investment, and land market participation: Evidence from Ethiopia. Land Economics, 87(2), 312-334. doi:10.3368/le.87.2.312

Deininger, K., Songqing J., Berhanu A., Samuel G. S. and Mulat D. (2003). "Land Tenure, Rural Land Transactions and Impacts on Farmers' Efficiency: Evidence from Ethiopia". World Bank WP No. 2992.

Deininger, K., Zevenbergen, J., \& Ali, D. A. (2006). Assessing the certification process of Ethiopia's rural Lands. In Colloque International, At the Frontier of Land Issues: Social Embeddedness of Rights and Public Policy, Montpellier, France.

Dejene Aredo (1999). The Role of Women in Rural Development in Ethiopia. In Tegegne Gebre Egziabher et al. (eds.), pp. 329 - 353.

Desalegn Rahmato (1994). Land Policy in Ethiopia at Cross-roads. In Dessalegn (ed.) Land Tenure and Land Policy in Ethiopia After the Derg. Norway: Reprocentralen AVH.

Desalegn Rahmato (2004). Searching for tenure security. The land system and new policy initiatives in Ethiopia, 51.

Desalegn Rahmato (2006). Land and the Challenge of Sustainable Development in Ethiopia. Addis Ababa: Forum for Social Studies

Desalegn Rahmato (2009). Rural land registration in Ethiopia. In: J. M. Ubink, A. J. Hoekema (Eds.), Legalising Land Rights: Local Practices, and Tenure Security in Africa, Asia and Latin America (pp. 59-95). Amsterdam: 
Leiden University Press.

EEA/EEPRI (2002). A Research Report on Land Tenure and Agricultural Development in Ethiopia, Addis Ababa: Ethiopian Economic Association (EEA) with the Ethiopian Economic Policy Research Institute (EEPRI).

Ege, S. (1997). The Promised Land: The Amhara Land Redistribution of 1997. Working Papers on Ethiopian Development No.12. Norwegian University of Trondheim.

Ege, S. (2017). Land tenure insecurity in post-certification Amhara, Ethiopia. Land Use Policy, 64, 56-63.

FDRE Constitution (1995). The Constitution of Federal Democratic Republic of Ethiopia. Addis Ababa.

Feder, G., T. Onchan, Y. Chalamwong, and C. Hongladarom (1988). Land policies and farm productivity in Thailand. Baltimore: Johns Hopkins University Press (for the World Bank).

Holden, S. T., Deininger, K., and Ghebru, H. (2009). Impacts of low-cost land certification on investment and productivity. American Journal of Agricultural Economics, 91(2), 359-373.

Holden, S., and Tewodros, T. (2008). Land Registration in Ethiopia: Early Impacts on Women, Summary report. United Nations Human Settlements Program (UN-HABITAT) Nairobi, Kenya. ISBN: 978-92-1-132014-5.

Mengesha, A. K., Mansberger, R., Damyanovic, D., \& Stoeglehner, G. (2019). Impact of Land Certification on Sustainable Land Use Practices: Case of Gozamin District, Ethiopia. Sustainability, 11(20), 5551.

Munoz, J. (1993). Rural land markets in Latin America: Evidence from four case studies (Bokivia, Chile, Honduras and Paraguay). Washington, D.C.: World Bank. (Processed).

Proclamation No. 133 (2006). The Revised Amhara National Regional State Rural Land Administration and Use Proclamation. Bahir Dar May 29,2006.

Samuel, G. (2006). Land, Land Policy and Smallholder Agriculture in Ethiopia: Options and Scenarios. Paper prepared for the Future Agricultures Consortium meeting at the Institute of Development Studies.

SARDP, B. (2010). Land Registration and Certification: Experiences from the Amhara National Regional State in Ethiopia. Booklet. Sida-Amhara Rural Devel-opment Program and Bureau of Environment Protection, Land Administration and Use (BoEPLAU).

Teketel Abebe (1998). Tenants of the State: The Limitations of Revolutionary Agrarian Transformation in Ethiopia, 1974-1991. Lund Dissertations in Sociology 24. Dept. of Sociology, Lund University, Sweden

Tesfaye Olika (2006). Ethiopia: Politics, Policy Making and Rural Development. Addis Ababa: Department of Political \& International Relations, Addis Ababa University. Pp. 1-25.

Tesfaye Teclu (2003). Rural lands and evolving tenure arrangements in Ethiopia. Discussion Paper no. 10. Addis Ababa: Forum for Social Studies.

Woldegebreal Daniel (2013). Land Rights and Expropriation in Ethiopia (Doctoral Thesis, Sweden, Royal Institute of Technology (KTH).

World Bank (1992). Ethiopia: Toward Poverty Alleviation and a Social Action Program. Report No. 11306-ET, November, World Bank, Washington D.C.

Yigremew Adal (2001a). Some Queries about the Debate on Land Tenure in Ethiopia. In Mulat Demeke and Tassew Woldemariam (eds.), Proceedings of the Tenth Annual Conference on the Ethiopian Economy, Ethiopian Economic Association, November.

Yigremew Adal (2002). Review of Landholding Systems and Policies in Ethiopia under the Different Regimes. Unpublished. Ethiopian Economic Association/Ethiopian Economic Policy Research Institute. Addis Ababa/Ethiopia. 